\title{
ULLERSMOPROSJEKTET: "SCARED STRAIGHT" I NORGE 1992-1996'
}

\author{
Av Elisabet E. Storvoll \& Arild Hovland
}

INNLEDNING

Ullersmoprosjektet, eller "Scared straight" som det også ble kalt, startet på Ullersmo. landsfengsel i 1992. Prosjektet ble lagt ned samme dag som sluttrapporten fra evalueringen ble offentliggjort (jf. Hovland og Storvoll 1997). I skrivende stund drives fremdeles et beslektet prosjekt ved Oslo kretsfengsel.

Konseptet til prosjektet ble i sin tid hentet fra det amerikanske "Juvenile Awareness Project" (JAP) i New Jersey, USA. (Se Lundman 1993, Finckenauer 1982 og Langer 1979 for en beskrivelse av JAP.) JAP og lignende tilnærminger til kriminalitetsforebygging var svært omstridt i USA på slutten av 70-tallet (Lewis 1983), men tilnærmingen lever fortsatt i beste velgående ved enkelte amerikanske fengsel, og den fortsetter å dukke opp den dag i dag.

Det ble også forsøkt med et lignende prosjekt ved Nyborg statsfengsel i Danmark på slutten av 80-tallet. (Se Kiberg 1992, Holt 1990 og Kyvsgaard 1990 for en beskrivelse av det danske prosjektet.) Det danske prosjektet ble imidlertid lagt ned etter kort tid.

\section{ULLERSMOPROSJEKTET}

Ullersmoprosjektet var et todelt prosjekt: (1) De innsatte reiste rundt og besøkte skoler, og (2) ungdom ble tatt inn i fengselet for en konfrontasjon med innsatte. Disse to delene hadde noe ulik målgruppe. Mens skolebesøkene rettet seg mot alle ungdommer, rettet fengselsbesøkene seg mot ungdom som ble antatt å ha problemer i forhold til kriminalitet og rusmisbruk. Det er disse fengselsbesøkene vi har evaluert.

Den uttalte målsettingen med fengselsbesøkene var å forebygge rus og kriminalitet. De prosjektansvarlige ville, i følge sin egen prosjektbeskrivelse, forebygge gjennom "å gi et virkelighetsbilde av det å være kriminell, være rusmisbruker og sitte i fengsel" (Nyborg og Korsvold 1995: 2).

Framgangsmåten var å ta såkalt problembelastet ungdom inn i fengselet for omvisning, og for at de innsatte skulle dele sine livserfaringer med dem. Forløpet i et "typisk" fengselsbesøk var som følger: Når ungdommene og personalet fra de institusjonene som tok dem med i prosjektet kom til Ullersmo landsfengsel, presenterte de unge seg over en dørtelefon. Der fikk de beskjed om å gå over fengselsområdet og melde seg $\mathrm{i}$ vaktboden. Først når ungdommene kom til vaktboden møtte de de fengselsbetjentene som skulle følge dem gjennom besøket. Fra nå av holdt institusjonspersonalet seg i bakgrunnen. De unge gikk først gjennom ulike kontroller, oftest en metalldetektor. Så ble de fulgt til de innsattes spisesal. Der ga en av fengselsbetjentene en orientering om fengselet. Deretter ble det gjennom- 
ført en arrangert konfrontasjon mellom ungdommene og de innsatte. Når denne konfrontasjonen var over, gikk hele følget ned til fengselets sikkerhetsavdeling. Der var det først omvisning. Så ble de unge delt i mindre grupper for å snakke med de innsatte inne på hver sine glattceller. Etter disse samtalene gikk de innsatte og ungdommene ut $\mathrm{i}$ en luftegård. Til slutt hadde de unge en samtale med fengselsbetjentene og ledsagerne fra institusjonen i et av fengselets besøksrom.

Det ble benyttet fryktproduserende virkemidler i tillegg til den informasjonen som ble formidlet under disse fengselsbesøkene. Dette gjaldt særlig under den delen av konfrontasjonen som fant sted i spisesalen. Eksempler på slike effekter er at de innsatte vekslet mellom vanlig tale og nærmest brøling, gikk tett opp i ansiktet til de unge, truet med vold, kastet salt- og pepperbøsser i veggen, og lot de unge gjennomføre ydmykende handlinger som å pusse skoene deres. Denne sekvensen ble konstruert for å produsere frykt og avmakt, og dermed læring. Det er med andre ord snakk om en form for avskrekking ("deterrence") av kriminalitet og rusmisbruk (jf. Lab 1988).

Ullersmoprosjektet var gjenstand for en omfattende mediedebatt etter at det ble presentert klipp fra et fengselsbesøk på norsk TV høsten 1994. Som en følge av denne debatten tok Barne- og familiedepartementet og Justisdepartementet initiativ til at prosjektet skulle evalueres.

I denne artikkelen diskuterer vi hvorvidt Ullersmoprosjektet var eksistensberettiget eller ikke. Dette spørsmålet belyses gjennom følgende delproblemstillinger:

- Hvorfor ble Ullersmoprosjektet startet opp og videreført?

- Hvorfor benyttet ulike institusjoner seg av prosjektet?

- Hvordan opplevde ungdommene å delta i prosjektet?

- Hva viser evalueringer av lignende tiltak?

- Hvilke etiske og juridiske problemstillinger aktiverer prosjektet?

\section{METODE}

Spørsmålet om hvorvidt Ullersmoprosjektet var eksistensberettiget eller ikke ble først og fremst besvart gjennom en prosessevaluering. Grunnlaget for evalueringsarbeidet var primært en antropologisk tilnærming. Vi beskrev selve fenomenet Ullersmoprosjektet, og de institusjonelle, sosiale, faglige/ideologiske og kulturelle sammenhengene det stod i. De institusjonelle sammenhengene knyttet Ullersmo landsfengsel til en rekke institusjoner i Norge, først og fremst de som benyttet seg av prosjektet, men også til lignende tiltak i USA. De sosiale sammenhengene knyttet de prosjektansvarlige til et nettverk av engasjerte personer spredt $\mathrm{i}$ blant annet barnevernet og fengselsvesenet. De kulturelle sammenhengene forbandt prosjektet til et fellesskap av noenlunde likt moralskt innstilte personer. De faglige eller ideologiske sammenhengene var først og fremst ideer om avskrekking av kriminalitet og rusmisbruk. Det var viktig for oss å se prosjektet fra flest mulig synsvinkler, for å kunne gi en samlet vurdering av det. Valg av evalueringsmetode beskrives nærmere i Hovland og Storvoll (1997) og Hovland og Storvoll (1995). 
Det datamaterialet som evalueringen bygger på ble i hovedsak innhentet gjennom dybdeintervjuer, deltakende observasjon og litteraturstudier.

De prosjektansvarlige ble intervjuet for å få kjennskap til hvordan Ullersmoprosjektet startet opp, og hvordan det ble drevet. Vi snakket nærmere bestemt med en representant for fengselsstyret, direktøren på Ullersmo landsfengsel og to av fengselets ansatte. Videre intervjuet vi seks av de innsatte som var involvert $\mathrm{i}$ prosjektet.

Det var 12 institusjoner/instanser som benyttet seg av Ullersmoprosjektet (heretter kalt brukerinstitusjoner). Representanter for disse ble intervjuet for å få kjennskap til de vurderinger som lå bak bruken av prosjektet, samt de erfaringer de satt igjen med. Ved de to institusjonene som hadde hatt med flest deltakere i prosjektet intervjuet vi to ansatte. Ved de øvrige snakket vi med én.

Til slutt intervjuet vi et utvalg av de ungdommene som deltok i prosjektet. Målet med disse intervjuene var å belyse deltakernes egne erfaringer fra- og synspunkter på prosjektet. Vi intervjuet til sammen 38 ungdommer, 29 gutter og 9 jenter. De fleste samtalene foregikk 1-4 år etter fengselsbesøket. ${ }^{2}$

I tillegg til å intervjue de partene som var involvert i Ullersmoprosjektet observerte vi ungdommenes fengselsbesøk. Vi var til stede under de fire konfrontasjonene som ble arrangert i evalueringsperioden. ${ }^{3}$ Videre bes $ø$ kte vi en av brukerinstitusjonene for å følge forberedelser og etterarbeid i forbindelse med to fengselsbesøk. Vi var der i tre dager: dagen før fengselsbesøket, den dag de besøkte fengselet og dagen etter. Ullersmoprosjektet hentet som nevnt ideen fra det amerikanske JAP. Dette prosjektet ble også besøkt i evalueringsperioden.

Litteraturen ble hovedsakelig hentet fra debatten omkring "Scared straight" $i$ amerikanske fagmiljøer og medier på slutten av 70-tallet, og evalueringer/studier av lignende amerikanske og et dansk tiltak. I tillegg ble litteratur som omtaler problemområdet mer generelt gjennomgått.

\section{RESULTAT}

Vi starter med å presenteres de involvertes perspektiver på Ullersmoprosjektet. Vi ser først hva de prosjektansvarlige og involverte innsatte sier. Deretter går vi inn på brukerinstitusjonenes og ungdommenes synspunkter. Til slutt går vi inn på evalueringer av lignende tiltak, og etiske og juridiske aspekter ved prosjektet.

\section{Hvorfor starte opp og drive Ullersmoprosjektet?}

Det var en rekke ansatte ved Ullersmo landsfengsel som i større eller mindre grad var involvert i Ullersmoprosjektet. Prosjektleder var imidlertid den samme i hele prosjektperioden. Videre var det ni innsatte som hadde deltatt $\mathrm{i}$ ett eller flere fengselsbesøk. I de første årene bar Ullersmoprosjektet preg av å være en tett sosial institusjon. Prosjektet var definert av hyppig kommunikasjon, og en opplevelse av fellesskap rundt et mål. Man mente man utrettet noe godt. I de innsattes tilfelle kan denne opplevelsen samles i to begreper: "å hjelpe ungdom til ikke bli som dem selv" og "å betale tilbake til samfunnet”. I de ansattes tilfelle lar forståelsen seg samle i 
formuleringen “å hindre ungdom i å ødelegge livet sitt”. La oss først gå inn på intervjuene med de innsatte.

De innsatte var samstemte i ønsket om å "informere" de unge bort fra den kursen de var inne på. Ved å gi de unge en "tankevekker", i form av kunnskap om sine egne livsløp og nåværende situasjon, håpet de å bevege de unge til ikke å gjøre det samme som dem selv. Videre sa flere at de ønsket å få de unge til å "innse" hva de holder på med. Innholdet i dette begrepet overlapper med uttrykk som å "helle en bøtte med kaldt vann i hodet på de unge", "få dem til å våkne" og "forstå konsekvensene av sine handlinger". Disse uttrykkene kan samles i termen "bevisstgjøring".

Flere innsatte ga uttrykk for at målet med selve konfrontasjonen var å få de unge til å "bryte sammen". Dette ble antydet i utsagn som "det tok lang tid, veldig lang tid, før han brøt sammen" og "noen ganger måtte vi gå litt hardere til verks for å få folk til å virkelig knekke". Målet var imidlertid ikke å provosere fram fullstendig oppløsning. Som en innsatt sa det:

Vi er ikke på jakt etter at folk skal begynne å grine. Det har ingen hensikt i seg sjøl. Men da er de så åpne som det går an å få blitt - og da er det veldig viktig å avslutte.

Konfrontasjonene skulle med andre ord "åpne" de unge slik at de var mottakelige for det budskapet de innsatte ville formidle dem. En innsatt betraktet det hele som en slags kirurgi.

Vi spurte de innsatte om de unge måtte bli redde? Svaret var ja, men synet på graden av frykt og måten denne skulle produseres på varierte. En innsatt som først avviste at det var nødvendig å skremme, gled over i et nyanserende argument. Det kommer jo an på situasjonen, påpekte han. Det kommer an på hvem man snakker med, hvor mottakelige de er. Hvis vi bare snakker rolig og vanlig, vil de kjede seg. Det ville gå en halv time, ikke mer. "En røst som plutselig blir forhøya, vil en ungdom reagere mer på, og kanskje høre litt bedre etter.” Hos denne innsatte var oppfatningen noe delt. På den ene siden ønsket og trodde han på informasjon og ro. På den andre siden fastholdt han nødvendigheten av å "heve røsten" om man skulle få alle til å høre etter. Uttrykket "heve røsten" fremstår imidlertid som mildt i forhold til det som var den generelle praksisen i prosjektet.

Det ble lagt vekt på at budskapet i seg selv var ment å være skremmende. Effektene man benyttet seg av skulle forsterke dette. En viss nervøsitet, og til dels også frykt, så de alle som nødvendig. Likevel var de i følge dem selv ikke så opptatt av dette på slutten som i begynnelsen. En innsatt fortalte at det helst var i starten at de var "litt vel opptatt av hyling og skriking", "slo i bordet" og "kastet stoler og bord fram og tilbake". Disse tingene forsvant i følge denne innsatte etter hvert som de "modnet som gruppe". Det er verdt å merke seg at denne "starten" etter alt å dømme varte til like før evalueringen tok til.

"Pedagogikken" hos de innsatte var enkel: Kunnskapen "satt" ganske enkelt ikke om den ikke ble inntatt $i$ kopling med en viss frykt. Frykten ble med andre ord antatt å skjerpe oppmerksomheten og styrke læringsprosessen. Samtidig skulle de unge 
oppleve følelsen av å sitte i fengsel når de var på Ullersmo. Opplevelsen av frykt ga i følge de innsatte et realistisk uttrykk for livet som innsatt. La oss også se på de ansattes synspunkter.

De ansattes synspunkter stemmer godt overens med det de innsatte står for. De unge må "skjønne konsekvensene" av sine handlinger, de må "konfronteres" med hva handlingene innebærer. Begge de ansatte ytret seg på samme måte. Det var imidlertid en gradsforskjell i synet på nødvendigheten av "støkk" eller "skremming". Mens den ene syntes å fastholde skremming som et element, tematiserte den andre det han forstod som skremselens begrensninger. Vedkommende reflekterte i en samtale over utviklingen av de ulike elementene i konfrontasjonen. De innsatte "skjønte at de ikke trengte å skrike", at de kunne "oppnå det samme, om ikke bedre resultater", ved en roligere tilnærming. De innsatte tonet det ned, fastslo han. Opplegget ble roligere, fordi "hvis du bare skriker og legger deg på det nivået, et høyt nivå, så lukker de unge seg inne og registrerer ikke hva som blir sagt". De forsvinner inn i et skall.

Ikke desto mindre så vi også hos denne ansatte den samme beredskapen i forhold til kraftigere virkemidler som vi så hos de innsatte. De innsatte "får heller slå til hvis det er behov for det, sånn innimellom, hvis de føler for det". De innsatte gjør det simpelthen for å få oppmerksomhet, fortalte han. En saltbøsse i gulvet "i ny og ne", eller et askebeger "som går i golvet", alt dette er nødvendig fra tid til annen. Man kan ikke stå og "messe" til folk, da hører de ikke etter. De unge må "våkne", og da er støkken viktig. Han tonet ned det faktum at saltbøsser ikke bare gikk i gulvet " $\mathrm{i}$ ny og ne", men hyppig, også i prosjektets siste fase.

\section{Hvorfor benyttet brukerinstitusjonene seg av prosjektet?}

Før vi går inn på institusjonenes begrunnelser for å bruke prosjektet, gir vi en kort beskrivelse av brukerinstitusjonene.

Det var til sammen 12 institusjoner/instanser som benyttet seg av Ullersmoprosjektet. Dette gjaldt blant annet barnevernkontor, utrednings- og behandlingsinstitusjoner, barne- og ungdomshjem, utekontakter, politistasjoner og alternative skoler. Det var både offentlige og private institusjoner blant brukerne.

Driftsmålsettingen til disse institusjonene er svært forskjellige. Enkelte er først og fremst boalternativer, mens andre driver forebyggende virksomhet. Andre igjen driver utrednings- eller behandlingsrettet arbeid. Selv om det er ulike typer institusjoner, har flere av dem et felles faglig ståsted: Flere fra institusjonene la under intervjuene vekt på at de arbeider etter en konsekvenstankegang. Enkelte sa eksplisitt at deres virksomhet tar utgangspunkt i konsekvenspedagogikk. ${ }^{4}$ Det kom dessuten fram at flere hadde en eller annen form for samarbeid med andre brukerinstitusjoner.

De fleste ledsagerne ${ }^{5}$ la vekt på at målet med fengselsbesøkene var å gi de unge en "realitetsorientering" eller "virkelighetsorientering". De ville vise dem hvordan det er i et fengsel. Andre begrunnelser som gikk igjen var at de ville vise ungdommene "konsekvensene" av det de holder på med, og at de ønsket å "avro- 
mantisere kriminaliteten". Enkelte argumenterte også med at de ville gi ungdommene en "vekker".

For enkelte så det ut til å ha ligget et element av straffi i fengselsbesøkene. En sa for eksempel at $\mathrm{i}$ tillegg til å gi de unge en mer realistisk holdning var målsettingen også "det som ulvene gjør når ulvungene er uskikkelige, rett og slett å ta de i kragen og riste de".

Det var bare en enkelt som vedgikk seg at de ønsket å skremme de unge. Han ga uttrykk for at de ønsket å forebygge gjennom "skremselspropaganda". Det at de fleste ikke ga eksplisitt uttrykk for at de ville skremme, står i motsetning til fengselets syn. Flertallet av de involverte i fengselet la, som vi har sett, nettopp vekt på at frykt er en vesentlig forutsetning for læring.

Hva ble så sagt om virkningene av prosjektet? De fleste ledsagerne ga uttrykk for at prosjektet hadde flere positive enn negative effekter på de ungdommene de hadde med til fengselet. De fleste mente at prosjektet ikke hadde noen negative virkninger. Når de ble bedt om å utdype de positive effektene, fikk vi svar som mindre kriminalitet, de fikk "revet ned" den romantiske forestillingen de hadde om fengselet, de "fikk opp øynene", mindre rusbruk, de begynte på skole eller i jobber og de ble lettere å snakke med. Det var imidlertid ikke alle ledsagerne som kunne peke på noen positive virkninger av prosjektet. Dette gjaldt også enkelte som mente at prosjektet hadde flere positive enn negative effekter.

Hvordan kan det ha seg at så mange institusjoner brukte prosjektet ved flere anledninger, eller ga uttrykk for at de kunne tenke seg å benytte det igjen, når de ikke entydig kunne peke på de positive virkningene prosjektet hadde? Tre svar utkrystalliserer seg på dette spørsmålet:

1) Handlingsberedskapen er stor. Det er med andre ord stor villighet til å forsøke de tilbudene som finnes på markedet (se punktet "Etiske og juridiske aspekter").

2) Det ble argumentert for at Ullersmoprosjektet hørte hjemme i en større sammenheng, og at det derfor måtte ses som en del av hele virksomheten. Med bakgrunn i dette hevdet de at det er vanskelig å skille virkningene av prosjektet fra virkningene av det øvrige tilbudet de unge gis.

3) Videre ble det argumentert for at Ullersmoprosjektet sannsynligvis hadde positive effekter siden det kan betraktes som en motsetning til tiltak som de opplever som lite hensiktsmessige. Det står i motsetning til tiltak som de opplever ikke virker fordi de er for "snille".

Viljen til - og behovet for positiv tolkning var med andre ord stor.

\section{Hvordan opplevde deltakerne Ullersmoprosjektet?}

Før vi går inn på deltakernes opplevelse av prosjektet, vil vi kort si noe om hvem som deltok i det.

Det var til sammen 144 ungdommer, 110 gutter og 34 jenter, som deltok i prosjektet. Alle var fra 13 til 19 år den gangen de var på Ullersmo. Flertallet var barneverns- 
klienter. De fleste av de vi intervjuet fortalte at de hadde vært involvert $\mathrm{i}$ ulike former for kriminalitet før de deltok i prosjektet. De hadde for eksempel vært med på innbrudd, biltyveri og salg av narkotika. Dette gjaldt imidlertid ikke alle. Enkelte hadde kun vært med på mindre alvorlige ting som ruteknusing og butikktyveri. Noen få hadde i følge dem selv ikke vært involvert i noen form for kriminalitet. Omtrent $1 / 3$ oppga at de brukte narkotiske stoff jevnlig og $1 / 3$ at de hadde eksperimentert med ulike rusmidler. Den siste tredjedelen sa at de kun hadde drukket alkohol, og da først og fremst i helgene.

Det uttalte målet med fengselsbesøkene var som sagt å gi de unge et "virkelighetsbilde av det å være kriminell, være rusmisbruker og sitte i fengsel". Flere deltakere la nettopp vekt på at de fikk et inntrykk av "sannheten" eller "virkeligheten" da de var på Ullersmo. En sa det slik:

"Det å være på Ullersmo, det er virkeligheta. Det er sånn det er. Det er de faktiske personene som forteller, som deler med deg, og ikke noen som leser fra en bok eller som har gått på skoler. Det er sånn det er.”

De unge benyttet seg som her ofte av de samme begrepene som ledsagerne og de involverte ved Ullersmo når de forsvarte prosjektet.

Det var imidlertid ikke alle som mente at de fikk et realistisk bilde av fengselet. Flere omtalte fengselsbesøket som et "skuespill". Andre mente at det ble overdrevet:

"Klart de overdriver litt. Skremsel. De prater som at folk går og hogger deg i ryggen annen hver dag liksom. Det skjer ikke. Det er ikke mulig. (...) De liksom la det frem sånn at det var fæelt, de daua hver dag og sånn, men det er litt feil beskrivelse syns jeg."

Nesten alle deltakerne vi snakket med ga uttrykk for at de ble skremt da de besøkte fengselet. Enkelte la vekt på at det var det de fikk se, og det de innsatte fortalte om fengselet, som skremte dem. Med andre ord selve informasjonen. Andre sa at de var mest redd for at de innsatte skulle gjøre dem noe mens de var der. De ble altså skremt av de fryktproduserende virkemidlene, og ikke det budskapet som ble forsøkt formidlet.

Det var imidlertid ikke alle som ble skremt. Noen kunne fortelle at de syntes det var spennende å være på Ullersmo (jf. "sensation seeking”). Flere av jentene fortalte dessuten at de ble betatt av de innsatte. En kunne også få inntrykk av at enkelte betraktet de innsatte som forbilder.

De fleste deltakerne ga uttrykk for at de er positivt innstilt til fengselsbesøket, og at de synes det er bra at de var med i prosjektet. Til tross for dette ga kun et fåtall (12 av 32) uttrykk for at prosjektet har hatt en positiv innvirkning på dem. De fleste mente at det hverken bidro til at de ble mindre kriminelle eller at de bruker mindre rusmidler. 


\section{Vesentlige trekk ved Ullersmoprosjektet}

Når vi studerte gjennomføringen av fengselsbesøkene og forberedelsene og oppfølgingen i forhold til de unge, ble vi slått av flere trekk. Forståelsen av prosjektet framsto ofte som ufullstendig og svakt underbygd. Resonnementene bar gjerne preg av inkonsistens og manglende relevant fagkunnskap. Det totale opplegget for besøkene var vanskelig å kontrollere, og det varierte fra gang til gang. Vi tar dette punkt for punkt.

Selve konfrontasjonsforløpet var etter alt å dømme kraftigere i formen, mer konfronterende, mer skremmende og mer uforutsigbar i det meste av prosjektperioden enn det vi kunne observere. Konfrontasjonene var med andre ord dempet $\mathrm{i}$ den perioden vi observerte dem. Dette framgikk av intervjuene med de unge så vel som de innsatte. De fengselsansatte hadde vanskeligere for å formidle dette til oss. Disse vanskene kan ganske enkelt skyldes at de ikke vet nok, ikke har sett alt som hadde skjedd. Det kan også skyldes at de ubevisst eller bevisst tonet ned de ubehagelige sidene ved prosjektet.

Intervjuene og observasjonene gjorde det klart at konfrontasjonene i svært stor grad ble definert av de innsatte. Det var den enkelte innsattes dagsform og holdninger, i tillegg til de øyeblikksrelasjoner som oppsto mellom dem og de unge, som var avgjørende. Kort sagt: Dersom en aggressiv innsatt møtte en ungdom han oppfattet som ekstra "frekk" eller "hard", ble konfrontasjonen gjerne svært sterk. Vi har bekreftet informasjon om fysisk håndgemeng og tilløp til slåssing. Vi vet at ungdom ble skjelt ut på det groveste, og at unge ble holdt opp etter veggen og truet. Videre foregikk det ydmykelser av unge besøkende som helt klart ikke er tillatt. Slike hendelser var heller unntaket enn regelen. Allikevel forteller de hvor svake de ansattes kontroll var, hvor liten oversikt de hadde, og hvor store muligheter for misbruk som var til stede.

De innsattes atferd og selve omgivelsene med murer, sikkerhetsceller, kontroller, ståldører, uniformer og innsatte som er fysisk preget av rus og kriminalitet utgjorde svært sterke virkemidler. Samlet sett gjorde dette at situasjonen ble omdefinert. Konfrontasjonene representerte ikke lenger et forsøk på kunnskapsformidling, men snarere målbevisste forsøk på produksjon av frykt og avmakt.

Fra prosjektledelsens side ble det ved en rekke anledninger gitt uttrykk for at forutsetningen for deltakelse var forberedelser og oppfølging i ettertid. Kommunikasjonen av disse forutsetningen var variabel i forhold til institusjonene. Det ble dessuten sjelden presisert hva disse forutsetningene skulle være. Det viste seg da også at oppleggene i institusjonene var svært varierende. For det meste var de svake, i noen tilfeller helt fraværende. En del ungdommer fikk ikke forberedelser, eller de ble forberedt på et rolig og informasjonsinnrettet besøk på Ullersmo. En stor del av forberedelsene ved den største brukerinstitusjonen besto av uformell kommunikasjon mellom de unge. Ved denne institusjonen ble besøket etterhvert forstått som en "manndomsprøve". Det var noe man måtte gjennom for ikke å tape ansikt i miljøet. Oppfølgingen i ettertid var også preget av tilfeldigheter. I beste fall fant det sted faste samtaler opp til et halvt år etter besøket. For de fleste unge handlet det om i høyden 
et halvtimes møte i institusjonen ved tilbakekomst fra fengselet. Den forutsetningen som de ansvarlige ved Ullersmo hele tiden hevdet lå til grunn for prosjektet, nemlig forberedelser og oppfølging fra institusjonene sin side, ble altså oftest enten ikke kommunisert til institusjonene, eller svakt eller ikke fulgt opp i det hele tatt.

La oss nå se hva evalueringer av lignende tiltak sier om effekten av den typen tilnærminger som Ullersmoprosjektet representerer.

\section{Evalueringer av lignende tiltak}

Det har vært mange prosjekter som likner på Ullersmoprosjektet i USA, og de fortsetter å dukke opp den dag i dag. Felles for dem er at de bruker fengsler og innsatte til forebygging av kriminalitet og rusmisbruk. Enkelte av disse prosjektene er svært konfronterende og aggressive, flere hakk kraftigere enn Ullersmoprosjektet, mens andre er mildere enn dette. Rammen rundt dem er også forskjellige. Noen involverer familiemedlemmer, mens andre består av flere fengselsbesøk. Videre varierer grad av oppfølging rundt fengselsbesøkene. Alle prosjektene handler imidlertid om å skjære igjennom, realitetsorientere, avskrekke, om voksnes ansvar for ungdom på skråplanet, og om disse unges ansvar for selv å hanke seg inn igjen. Mange av argumentene for de amerikanske prosjektene er til forveksling lik de vi fant knyttet til Ullersmoprosjektet.

De amerikanske prosjektene har blitt evaluert en rekke ganger, dels ved hjelp av ulike tilnærminger. Vi valgte å se nærmere på de amerikanske effektevalueringene, da vi mener disse kan gi oss noen indikasjoner på hvilke effekter Ullersmoprosjektet hadde. Vi gikk gjennom de 14 effektevalueringene vi fikk tak i i evalueringsperioden. (Se Hovland og Storvoll (1997) for en nærmere beskrivelse av disse evalueringene.) Omtrent halvparten av disse evalueringene var basert på sanne eksperimenter, resten var basert på kvasi-eksperimenter. Alle disse studiene målte registrert kriminalitet i tiden før og etter fengselsbesøket.

De fleste evalueringene fant ingen effekter av fengselsbesøket. De unge ble skremt eller konfrontert til ingen nytte. Et par evalueringer fant negative resultater, det vil si mer kriminalitet etter besøket enn før. Dette gjaldt for eksempel det ennå eksisterende JAP i New Jersey. Tre evalueringer fant positive resultater. Det knytter seg imidlertid betydelige metodologiske svakheter til disse tre evalueringene. De amerikanske evalueringene er generelt sett kvalitetsmessig ujevne. Allikevel, peker de aller fleste evalueringene i retning av at disse prosjektene ikke hadde noen forebyggende effekt. Med utgangspunkt i de amerikanske evalueringene går altså konklusjonen $\mathrm{i}$ retning av at denne typen tilnærminger ikke forebygger kriminalitet og rusmisbruk blant ungdom.

Den generelle kriminologiske og psykologiske litteraturen vi har sett på peker i samme retning som de konkrete evalueringene. Forebygging av kriminalitet og rusmisbruk skjer ikke gjennom fryktproduksjon. Man risikerer snarere å produsere negative forbilder eller modeller for de allerede belastede unge: Man risikerer å skyve dem i retning av en forverring av selvbilde og atferd (jf. Schneider 1990). Konfrontasjonsprosjektenes implisitte forutsetninger om at unge mennesker er 
rasjonelle og vurderingsdyktige i forhold til rus og kriminalitet avvises også (jf. Schneider 1990).

Det finnes altså ikke grunnlag for støtte til konfrontative og fryktproduserende rehabiliteringsforsøk av ungdom belastet med rus og kriminalitet i det amerikanske materialet. Siden denne forskningen spenner over svært varierte prosjekter, mener vi disse forskningsresultatene kan si noe om effektene av Ullersmoprosjektet.

I denne artikkelen refereres kun evalueringer som har studert slike prosjekters effekter på deltakende ungdom. Enkelte studier har også lagt vekt på hva slike prosjekt betyr for de innsatte. Se Hovland og Storvoll (1997) for en nærmere diskusjon av dette.

\section{Etiske og juridiske aspekter}

La oss for et øyeblikk forutsette at det er stor sannsynlighet for at Ullersmoprosjektet hadde forebyggende effekt. Er det da slik at prosjektet var tillatelig? Tilnærmingens kritikere mener nei. La oss kort referere deres synspunkter fra debatten omkring prosjektet høsten 1994.

Falck (1994: 7) hevdet at "'"Scared Straight!" går [...] langt over grensen". Et tiltak skal være etisk forsvarlig også om det rettes mot ungdom med atferdsproblemer. "Det er ikke alltid slik at hensikten helliger midlet." Det er ikke "fritt fram" for hvilke som helst tiltak. Falcks syn er kort sagt at prosjektet var utillatelig.

Mathiesen (1994a og 1994b) benyttet i stor grad de samme argumentene som Falck. Tyngden var imidlertid ennå sterkere på de etiske aspektene. Han var øyensynlig oppskaket over det han i utvetydige ordelag betegnet som et "rystende brudd på fundamentale prinsipper for anstendig behandling av mennesker" (Mathiesen 1994a). Han påpekte at det finnes grenser, for hva man kan gjøre selv om det er effektivt. Ullersmoprosjektet overskrider i følge ham disse grensene: Behandlingen de unge gis "setter grunnleggende verdier om menneskelig integritet og verdighet til side".

Tredje bidragsyter blant kritikerne, Jansen (1994: 18), la også vekt på at "sjokkterapien" ved Ullersmo på ingen måte kunne forsvares. Han påpekte at de ansvarlige for prosjektet "under dekke" av begreper knyttet til forebygging, pedagogikk og behandling kunne "utføre overgrep". Handlingene som ble utført ved Ullersmo ble sidestilt med "gestapist-metoder uten ideologisk og verdimessig grunnlag". Konklusjonen var utvetydig: Denne tilnærmingen ved Ullersmo hadde ingen verdi, hverken med hensyn til resultater eller i forhold til moralske standarder.

Det siste kritiske innlegget vi tar for oss ble skrevet av Løfwander og Knutsen (1994: 4). Deres overordnede holdning ble signalisert alt i undertittelen: "Når tvang blir maktmisbruk og maktovergrep kalles behandling." Det ideologisk-pedagogiske grunnlaget for Ullersmoprosjektet ble her sidestilt med "den sorte pedagogikk", en forestilling om at lydighet oppnådd gjennom tvang "er en dyd".

Så langt de klareste kritikerne av Ullersmoprosjektet. Hovedbudskapet hos disse er at prosjektet var moralsk forkastelig enten det virket eller ikke. Mulighetene for en bro over til de som støtter tilnærmingen synes altså små. 
For enkelte institusjoner som benyttet seg av Ullersmoprosjektet veies etikken som anvendes i forhold til de unge konsekvent i forhold til de mål man har satt seg. Den er målorientert, pragmatisk og situasjonelt avgrenset. De prinsipielt viktige spørsmålene knyttes ikke til "tvang" eller "ikke-tvang". De knyttes til det ansvar behandlere har for å ta hånd om ungdom som ikke selv kan ta ansvar. Det moralsk forkastelige ligger ikke $\mathrm{i}$ inngrepet, men $\mathrm{i} a ̊$ la være å gripe inn når det finnes virksomme metoder. Fravær av handling - eller ineffektiv handling - er forkastelig der andre muligheter eksisterer. La oss se på noen av de formuleringene de involverte i Ullersmoprosjektet benyttet seg av.

"Hvis vi i vår ungdom hadde gjennomgått sjokkterapien kunne kanskje mye vært annerledes i våre egne liv." Dette er kanskje den viktigste formuleringen, og en gjenganger hos de innsatte. De innsatte tok her utgangspunkt i den tankeoperasjonen de vanligvis anvendte overfor de unge som kom på besøk, en samkategorisering, og hevdet at deres egne livsløp kunne vært dramatisk annerledes om bare noen hadde grepet inn på samme vis overfor dem selv. Heri ligger etikken, $i$ en form for ansvarliggjøring av seg selv og alle voksne, og i en logikk som tilsier at den som har virkemidler er forpliktet til å bruke dem.

"Om så bare én får hjelp..." var en annen sentral del av forsvaret for prosjektet. På denne måten ble argumentet om svake resultater tilbakevist som ubetydelig. Det var verdt det likevel. Logikken er at den som lar være å handle når han kan - om han så bare hjelper den ene - er den som handler uetisk. Den ene er unik og må ivaretas for enhver pris. Dette resonnementet løper direkte over i det neste.

"Det er resultatet som teller..." Konsekvensen er at resultatet relativiserer, og dels setter til side, de høyst diskutable aspektene ved metoden. Selve framgangsmåten relativiseres også, og bidrar til å gjøre prosjektet mindre problematisk. Vi ble ved en rekke anledninger fortalt, av ansatte så vel som innsatte, at prosjektet ble tonet ned, at man "kjørte hardere" og var mer skremmende før. Prosjektet som helhet ble dermed omdefinert i kraft av sin status som avdempet i siste fase.

Handlingslogikken $i$ Ullersmoprosjektet ser altså ut til å ha vart langt mer grunnleggende enn de etiske overveiningene. Man så et problem, øynet en mulig løsning, hadde klare betraktninger om denne verdens brutalitet og behovet for handling, var relativiserende eller avvisende i forhold til lovverkets påbud eller forbehold - og handlet. Handlingen var primær, ikke de problematiske aspektene ved handlingen. I den grad det handlet om etikk, var dette en etikk som ikke tok sitt utgangspunkt i systematiske og nyanserte refleksjoner. Slike refleksjoner ble ikke nødvendigvis betraktet som overflødige. Det er heller ikke tilfelle at de ble utelatt, slik som noen kritikere synes å mene. Men de ble stadig relatert til målet for handlingen. Etikken ble relatert til handlingsansvaret, ikke til handlingens problematiske aspekter i et moralfilosofisk eller juridisk perspektiv. Dermed ble det også vanskelig for henholdsvis tilhengere og motstandere å møtes. Man kan med et bilde si at de simpelthen ikke spilte på samme bane. Argumentene ble hentet fra vidt forskjellige kilder. Der hvor den ene var realistisk tilstede i en hverdag hvor det handlet om å få jobben gjort med de midler som fantes, var den andre opptatt av at 
det finnes grenser man ikke kan overskride selv i det godes tjeneste. Så lenge regelverket kan sies å gi rom for tolkning og skjønn, hvilket det gjør (jf. Faggruppe i Barne- og familiedepartementet, 1995), vil muligheten for etisk relativisering være der. Stilt overfor uttrykkene "nothing works" og "anything goes", ville tilhengerne av Ullersmoprosjektet per nødvendighet og moralsk, avviste det første og tenderte i retning av det siste.

Det var vanskelig å gripe inn overfor Ullersmoprosjektet. Ulike tolkninger av lovverk og etiske rammer ble stående mot hverandre. Etisk høyverdige argumenter kunne anføres på begge sider. Det samme gjaldt de juridiske forholdene. Ble tilhengernes argumenter supplert med særegne tolkninger av hva som faktisk foregikk, ble det enda vanskeligere å gripe inn. De kunne jo ha rett. Tolkningene kunne ha noe for seg.

Konklusjonen må bli at de etiske og juridiske problemstillingene i dette tilfellet er tett sammenvevd. Det ene aspektet lar seg vanskelig vurdere uten at det andre tas i betraktning. Stor etisk "romslighet" disponerer for en vid og særegen - og kanskje utillatelig - fortolkning av relevante lover og regler. Det må bli opp til juristene å avgjøre hvorvidt Ullersmoprosjektet generelt sett var et eksempel på utillatelig fortolkning av gjeldende regelverk. Tilnærmingen bevegde seg imidlertid uten tvil $i$ et tillatelighetens grenseland, ikke bare etisk, men også juridisk. Det er heller ikke tvil om at grensene utvetydig ble krysset ved flere anledninger.

\section{OPPSUMMERING OG AVSLUTTENDE KOMMENTARER}

Evalueringen konkluderte med at Ullersmoprosjektet, og den tilnærmingen prosjektet representerer, ikke kan forsvares på faglig grunnlag. Dette vil, som vi har sett, si tre ting:

1) Prosjektets praksis, altså gjennomføringen av fengselsbesøkene og forberedelser og etterarbeid ved brukerinstitusjonene, var uforsvarlig, også i forhold til de kriterier de ansvarlige selv hadde lagt til grunn.

2) En rekke handlinger som konstituerte tilnærmingen beveger seg etisk og juridisk sett $\mathrm{i}$ et grenseland i forhold til hva som er tillatt å gjøre i forhold til ungdom belastet med rus og kriminalitet. I praksis ble denne grensen krysset ved en rekke anledninger.

3) Sett fra et nytteperspektiv, finner vi ikke grunnlag for å si at den tilnærmingen Ullersmoprosjektet representerer bidrar til reduksjon i kriminalitet og rusmiddelmisbruk hos ungdom.

Ullersmoprosjektet var et importprodukt $\mathrm{i}$ Norge, en lånt amerikansk tilnærming. Men det ble plantet i fruktbar jord. Det var, og er, mottakelighet for slike tilnærminger i deler av barnevernet og fengselsvesenet. Dette gjelder særlig de delene av disse to samfunnssfærene som baserer seg på privat og personlig initiativ, og som delvis bygger på svake faglige overveininger.

Prosjektet uttrykte en nesten voldsom handlings- og inngrepsvilje i noen miljøer. En rekke mennesker som har ansvar for vanskeligstilte barn og unge mener at det tradisjonelle barnevernet er for lite handlekraftig. De er innstilt på å skjære igjen- 
nom. Det er en høyere vurdering eller rangering av handling enn av de eventuelle begrensningene man kan legge på handlingen.

Prosjektet demonstrerte også en særegen kombinasjon av svak eller "forstyrret" barnevernfaglig kompetanse, koplet med en slags forakt for relevante kategorier "fagfolk" og akademikere. Man mener disse er preget av liten praktisk innsikt og svak realitetssans. Den samme forakten retter seg for øvrig mot det man betrakter som naive lover og regler. Som en sa det, lover og regler eller rettssikkerhet, har en tendens til å "blande seg inn på ganske mange terapeutiske nivåer".

Kombinerer vi disse trekkene med det faktum at feltet har sin porsjon karismatiske enkeltpersoner og miljøer som har mer preg av åndelig enn av faglig fellesskap, må konklusjonen bli at selv om Ullersmoprosjektet nå er stanset, vil det ganske sikkert oppstå nye prosjekter eller tiltak i samme ånd, og delvis befolket av de samme menneskene.

\section{Noter:}

1 Denne teksten er en bearbeidet versjon av et foredrag holdt på Nordisk Samarbeidsråd for Kriminologi sitt forskerseminar 1997 i Hirtshals, Danmark, 22.-25. mai 1997.

2 Noen få deltakere ble i tillegg intervjuet før fengselsbesøket. Vi la opprinnelig opp til å følge et utvalg av deltakere fra uken før deltakelsen til et halvt år etter. Dette lot seg av praktiske grunner ikke gjennomføre.

3 Det ble arrangert en femte konfrontasjon. Denne har ikke inngått i evalueringsprosjektet da den ble betegnet som et privat opplegg for en bekjent av en av fengselets ansatte.

${ }^{4}$ Konsekvenspedagogikken beskrives blant annet i Bay (1982).

5 Ansatte ved institusjoner/instanser som har benyttet seg av Ullersmoprosjektet.

\section{LITTERATUR}

Faggruppe i Barne- og familiedepartementet (1995): Utredning av de faglige forutsetningene for arbeid med ungdom plassert etter lov om barnevernstjenester $\$ \S 4-24$ og 4-26. Oslo: Barne- og familiedepartementet, Barne- og ungdomsavdelingen.

Bay, J. (1982): Avvikerne og ansvaret. På vei mot konsekvenspedagogikk. Oslo: Cappelens Forlag.

Falck, S. (1994): Skremmende avmakt. Norges Barnevern, 4, 4-7.

Finckenauer; J.O. (1982): Scared Straight! and the Panacea Phenomenon. Englewood Cliffs, New Jersey: Prentice Hall.

Holt, C. (1990): Skrcemt til lovlydighed. Nyt fra kriminalforsorgen, 2, 10-11.

Hovland, A. og Storvoll, E.E. (1995): "Ullersmoprosjektet" Evalueringstapport nr: 1. UNGforsk-rapport 5/95. Oslo: UNGforsk.

Hovland, A. og Storvoll, E.E. (1997): På rett kjøl? Ullersmoprosjektet 1992-1996. NOVA-rapport 1/97. Oslo: Norsk institutt for forskning om oppvekst, velferd og aldring. 
Jansen, U. (1994): Behandling i redselskabinettets ånd. Med redsel, angst og utrygghet skal verdighet bygges! Fontene, 18-19.

Kiberg, C. (1992): Unge lod sig ikke skrcemme til lovlydighed. Nyt fra kriminalforsorgen, 5.

Kyvsgaard, B. (1990): Skrcemt til lovlydighed? Dansk forsøg med aversionsterapi. I: Kyvsgaard, B.; Snare, A. og Wilhjelm, P. (Red.): Forebyggelsens veje og vildveje. København: Kriminalistisk Institut.

Lab, S.P. (1988): Crime Prevention. Approaches, Practices and Evaluations. Cincinnati, Ohio: Anderson Publishing Co.

Langer; S. (1979): The Rahway State Prisons Lifers' Group: A Critical Analyses. Kean College of NJ, Department of Sociology and Social Work.

Lewis, R.V. (1983): Scared Straight - California Style. Evaluation of the San Quentin Squires Program. Criminal Justice and Behavior, 10 (2), 209-226.

Lundman, R.J. (1993): Prevention and Control of Juvenile Delinquency. New York: Oxford University Press.

Løfwander, E. og Knutsen, G. (1994): "Scared Straight"-kan ungdom skremmes til lovlydighet? Barnevernspedagogen, 4, 4-7.

Mathiesen, T. (1994a): Skrekkbehandling på Ullersmo. Replikk i Dagbladet 10. september 1994.

Mathiesen, T. (1994b): Litt til om skrekkbehandling. Replikk i Dagbladet 31. oktober 1994.

Nyborg, F. og Korsvold, J. (1995): Prosjektbeskrivelse "Ullersmoprosjektet". Upublisert.

Schneider; A.L. (1990): Deterrence and Juvenile Crime. Results from a National Policy Experiment. New York: Springer-Verlag.

Adresser: Forsker Elisabet E. Storvoll

Norsk institutt for forskning om

oppvekst, velferd og aldring (NOVA)

Munthesgate 29, N-0260 Oslo

Tlf. +4722541200

Fax +4722541201

E-post elisabet.storvoll@isaf.no

Forsker Arild Hovland

Norsk institutt for forskning om

oppvekst, velferd og aldring (NOVA)

Munthesgate 29, N-0260 Oslo

Tlf. +4722541200

Fax +4722541201

E-post arild.hovland@isaf.no 